\title{
Struktur Morfoanatomi Bunga, Daun dan Akar Salak Pondoh (Salacca edulis Reinw.) pada Beberapa Daerah di Kabupaten Magelang
}

\author{
Morphological Structure of Flower and Root Anatomy of Salak Pondoh \\ (Salacca edulis Reinw.) in Several Areas in Magelang Regency \\ Erma Prihastanti* dan Sri Haryanti \\ Program Studi Biologi Fakultas Sains dan Matematika Universitas Diponegoro \\ *Email: eprihast@yahoo.co.id
}

Diterima 20 Agustus 2020 / Disetujui 7 Oktober 2020

\begin{abstract}
ABSTRAK
Salak merupakan tanaman buah asli dari Indonesia. Varietas salak juga berbagai macam, salah satunya adalah salak pondok yang terkenal komoditas unggul dari DI Yogyakarta dan sekitarnya. Penelitian ini menggunakan rancangan acak lengkap (RAL), dengan satu faktor yaitu: lokasi pengamatan yang berbeda. Lokasi atau daerah tersebut adalah Salamsari, Ngablak, dan Banyuadem. Ketiga daerah tersebut berada di Kabupaten Magelang, Jawa Tengah, dimana secara geografis terletak dekat DIY yang terkenal dengan salak pondohnya. Parameter yang digunakan adalah jumlah tangkai, jumlah tandan, keliling bunga dan buah, panjang bunga, serta ukuran stomata. Selain itu, diamati juga anatomi akar tanaman salak pondoh. Penelitian ini bertujuan untuk mengetahui perbedaan morfologi bunga dan anatomi akar salak pondoh pada daerah yang berbeda di Kabupaten Magelang. Hasil dari penelitian ini adalah tidak terdapatnya perbedaan nyata pada morfologi bunga maupun ukuran stomata yang diamati. Sedangkan, anatomi akar berbeda pada susunan sel korteks pada lahan recovery lebih rapat dan beraturan dan pada lahan unrecovery, susunan sel korteks akar lebih tidak beraturan dan banyak rongga udara.
\end{abstract}

Kata kunci : keliling bunga, salak, tandan

\section{ABSTRACT}

Salak is a native fruit plant from Indonesia. There are also many varieties of salak, one of which is salak pondok which is known as a superior commodity from DI Yogyakarta and its surroundings. This study used a completely randomized design (CRD), with one factor, namely: different observation locations. These locations or areas: Salamsari, Ngablak, and Banyuadem. The three areas are located in Magelang Regency, Central Java, which is geographically located near Yogyakarta and famous for its salak pondoh. The parameters used were the number of stalks, the number of bunches, the perimeter of the flowers and fruit, the flowers length, and the size of stomata. the root anatomy of the salak pondoh plant was also observed. This study aims to determine the differences in flower morphology and root anatomy of salak pondoh in different areas in Magelang Regency. The results of this study were that there was no significant difference in the morphology of the flowers and the size of the observed stomata. Meanwhile, the root anatomy is different in that the cortex cell arrangement in the recovery area is more dense and regular and in the unrecovered area, the cell arrangement of the root cortex is more irregular and there are many air cavities.

Keywords : flower perimeter, salak, bunch

\section{PENDAHULUAN}

Salak adalah salah satu anggota family Arecaceae, biasanya disebut juga snake fruit. Buah ini disebut snake fruit karena memiliki kulit bersisik berwarna coklat kemerahan (Herawati et al,
2018). Salak juga memiliki kandungan antioksidan yang tinggi (Saleh et al, 2018). Tanaman salak merupakan tanaman asli Indonesia (Girsang et al, 2019). Salah satu jenis salak adalah salak pondoh Salak pondoh mulai dikembangkan tahun 1980an, salak yang manis dan garing ini menjadi buah 
primadona yang penting di wilayah DIY (Hastuti, 2013) dan sekitarnya. Beberapa masyarakat juga menggunakan tanaman salak menjadi sebuah produk yang bermanfaat (Joshua dan Sinuraya, 2018). Oleh karena itu, produksi salak mengalami peningkatan selama 3 tahun terakhir ini. Berdasarkan data BPS (2019), produksi salak provinsi Jawa Tengah sebesar 482.949 ton dan produksi pada skala nasional mencapai 955.768 ton, angka produksi ini mengalami peningkatan dari tahun sebelumnya.

Tanaman salak banyak memiliki varietas diantaranya memiliki sifat-sifat unggul, baik dari segi rasa maupun dari penampilan buah. Varietas salak dibedakan berdasarkan tekstur daging buah, warna kulit buah, besar buah, aroma dan rasa daging buah. Salah satu salak yang terkenal adalah Salak pondoh yang berasal dari daerah Yogjakarta dan sekitar (Herawati dkk, 2012).

Menurut penelitian Fatimah (2013) terhadap 11 kultivar salak, sifat morfologis yang diamati terdiri dari 37 karakter dan terdapat 12 karakter morfologi yang sama, 9 di antaranya terdapat sebagian persamaan, sedangkan 16 karakter morfologi yang memiliki perbedaan. Pulakiang dkk (2017) mengungkapkan bahwa pengamatan morfologis berguna untuk mengetahui pengembangan budidaya tanaman salak melalui pemuliaan. Hal inilah yang mendorong terjadinya penelitian ini. Penelitian ini bertujuan untuk mengetahui perbedaan morfologi bunga dan anatomi akar salak pondoh pada daerah yang berbeda di Kabupaten Magelang. Hasil akhir dari penelitian ini diharapkan dapat digunakan sebagai bahan acuan maupun informasi bagi pengembangan salak di masa yang akan dating, sehingga menghasilkan salak yang berkualitas dan tinggi nilai jual ekonominya.

\section{METODE PENELITIAN}

Penelitian dilakukan di kebun Salak pondoh di Kabupaten Magelang. Penelitian ini menggunakan rancangan acak lengkap (RAL), dengan satu faktor yaitu daerah di Kabupaten Magelang. Terdapat 3 daerah yang menjadi lokasi penelitian, yaitu Salamsari, Ngablak, dan Banyuadem. Parameter yang digunakan adalah jumlah tangkai, jumlah tandan, kelilig bunga dan buah, panjang bunga, dan ukuran stomata, serta anatomi akar tanaman salak. Data yang didapat akan dianalisis menggunakan One-way Test (uji satu arah) pada tingkat signifikansi 95\% dan uji lanjutan dengan uji DMRT (Duncan's Multiple Range Test).

\section{Pengamatan Morfologi Bunga}

Pengamatan morfologi bunga tanaman salak dilakukan saat pohon salak mengalami fase pembungaan. Morfologi bunga diamati dengan 5 ulangan tiap parameter pada masing-masing lokasi penelitian. Saat dilakukan pengamatan, juga didokumentasikan.

\section{Pengamatan Anatomi Akar}

Pengamatan anatomi akar tanaman salak dilakukan di laboratorium biologi struktur dan fungsi Departemen Biologi, Universitas Diponegoro Semarang, dengan menggunakan mikroskop. Akar yang diamati memiliki ukuran 2 $\mathrm{mm}$ dan 3-5 mm, masing-masing dengan 3 ulangan.

\section{HASIL DAN PEMBAHASAN}

\section{Morfologi Bunga}

Berdasarkan Tabel 1, dapat disimpulkan bahwa setelah data dianalisis dengan one-way test, pada parameter jumlah tangkai, jumlah tandan, keliling bunga dan buah, serta panjang bunga, tidak meunjukkan perbedaan yang signifikan. Jumlah tangkai dan jumlah tandan tertinggi ada di Ngablak, keliling buah dan bunga tertinggi berada di Banyuadem, dan Salamsari hanya hanya memiliki angka tertinggi pada parameter panjang bunga, yaitu $19,6 \mathrm{~cm}$.

Bentuk seludang bunga pada semua kultivar salak bentuknya memanjang, sedangkan untuk jumlah tandan terdapat 2 kelompok, yaitu: antara 1 atau 2 tandan dan 3 atau lebih tandan bunga per seludang (Fatimah, 2013). Buah salak termasuk jenis buah yang mempunyai ukuran buah sedang, ukuran dari buahnya juga bergantung pada jenis varietas salak itu sendiri. Umumnya panjang (ukuran buah) sekitar 2,5-10 cm (Zaed, 2015). 
Tabel 1. Hasil analisis rata-rata jumlah tangkai, jumlah tandan, keliling bunga dan buah, serta panjang bunga tanaman salak pondoh beberapa daerah di kabupaten Magelang

\begin{tabular}{lccccc}
\hline \multirow{2}{*}{ Lokasi } & \multicolumn{5}{c}{ Parameter } \\
\cline { 2 - 6 } & $\begin{array}{c}\text { Jumlah } \\
\text { Tangkai }\end{array}$ & Jumlah Tandan & $\begin{array}{c}\text { Keliling Bunga } \\
(\mathrm{cm})\end{array}$ & $\begin{array}{c}\text { Keliling Buah } \\
(\mathrm{cm})\end{array}$ & $\begin{array}{c}\text { Panjang Bunga } \\
(\mathrm{cm})\end{array}$ \\
\hline Salamsari & 7.6 & 1.2 & 7 & 13.89 & 19.6 \\
Ngablak & 8.2 & 2.6 & 6.3 & 11.42 & 16.2 \\
Banyuadem & 7.4 & 2.2 & 8.4 & 17.92 & 16.8 \\
\hline
\end{tabular}

\section{Ukuran Stomata}

Berdasarkan Tabel 2, dapat disimpulkan bahwa setelah data dianalisis dengan one-way test, pada parameter ukuran stomata baik secara vertical maupun horizontal, tidak terdapat perbedaan nyata pada tingkat signifikansi $95 \%$,. Ukuran stomata terbesar secara vertical $(80,63 \mu \mathrm{m})$ pada salak pondoh Salamsari, sedangkan secara horizontal, terbesar pada Ngablak yaitu sebesar 75,91 $\mu \mathrm{m}$.

Faktor yang mempengaruhi perbedaan stomata adalah kondisi lingkungan yang ada. Pada saat perbedaan stomata di embrio pucuk daun sangat mempengaruhi proses ini. Tersedianya air, intensitas cahaya, dan suhu memperlihatkan pengaruh penting (Zelitch, 2018).

Stomata merupakan pintu utama bagi masuknya $\mathrm{CO} 2$ ke dalam daun, yang pada gilirannya akan mempengaruhi kapasitas fotosintesis tanaman. Ukuran stomata secara vertical berhubungan dengan lebar pori stomata (ukuran secara horizontal), Menurut Taluta dkk (2017), dalam proses difusi $\mathrm{CO} 2$ ke dalam jaringan daun, stomata yang membuka lebih kecil difusi $\mathrm{CO} 2$ lebih rendah dibanding pada daun yang stomatanya membuka lebih besar.

Tabel 2. Rerata ukuran stomata salak pondoh secara vertikal maupun horizontal

\begin{tabular}{lcc}
\hline \multirow{2}{*}{ Lokasi } & \multicolumn{2}{c}{ Ukuran Stomata $(\mu \mathrm{m})$} \\
\cline { 2 - 3 } & Vertikal & Horizontal \\
\hline Salamsari & 80,63 & 73,94 \\
Ngablak & 77,09 & 75,91 \\
Banyuadem & 73.55 & 73.95 \\
\hline
\end{tabular}

\section{Anatomi Akar}

Sayatan melintang akar salak pondoh (Salacca edulis Reinw.) pada lahan recovery dan unrecovery ditunjukkan pada Gambar 1 sampai Gambar 4. Menurut Hakim dkk (2020), recovery adalah mekanisme dimana tanaman yang terkena cekaman kekeringan mampu memulihkan kembali pertumbuhan yang terhambat akibat cekaman kekeringan dengan mulai mendapat suplai air yang cukup. Berdasarkan Gambar 3 dan Gambar 4, pada lahan unrecovery, rongga udara (aerenkim) terlihat besar daripada akar dari tanaman salak lahan recovery. Akar merupakan organ penting pada tanaman terutama untuk menyerap air dan unsur hara pada media tanam (Fenta at al, 2014). Tanaman lebih banyak mengembangkan sistem perakaran dalam menanggapi cekaman atau kekurangan unsur hara (Lynch dan Brown, 2012).

Anatomi akar lahan unrecovery menunjukkan susunan sel yang tidak rapat dan tidak beraturan, dan terdapat rongga udara yang besar. Hal ini menunjukkan bahwa lahan unrecovery yang ditanami salak pondoh, akan menjadikan anatomi akar yang berbeda dengan lahan recovery. Penelitian Suharti dkk (2017) mengungkapkan cekaman kekeringan yang diberikan pada tanaman akan menghasilkan ukuran sel jaringan mesofil yang lebih kecil.

Anatomi akar dapat berbeda dikarenakan keadaan lahan atau tempat tumbuh yang berbeda. Menurut Widyantika (2018), akar tanaman salak memiliki daerah penyebaran yang tidak luas, dangkal, dan mudah rusak jika kekurangan air. 


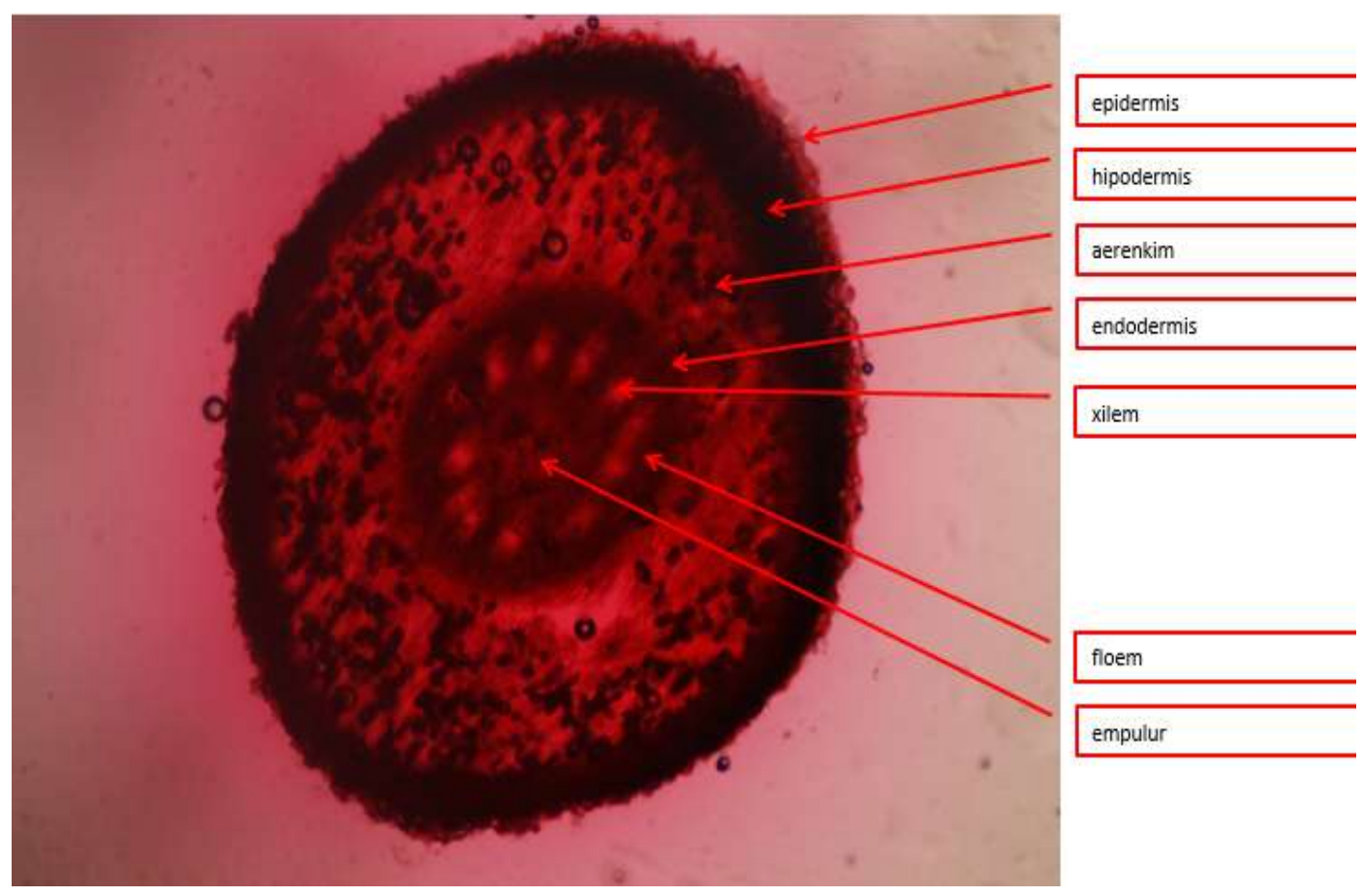

Gambar 1. Anatomi akar $2 \mathrm{~mm}$, pada lahan recovery $(\mathrm{M}=40 \mathrm{x})$
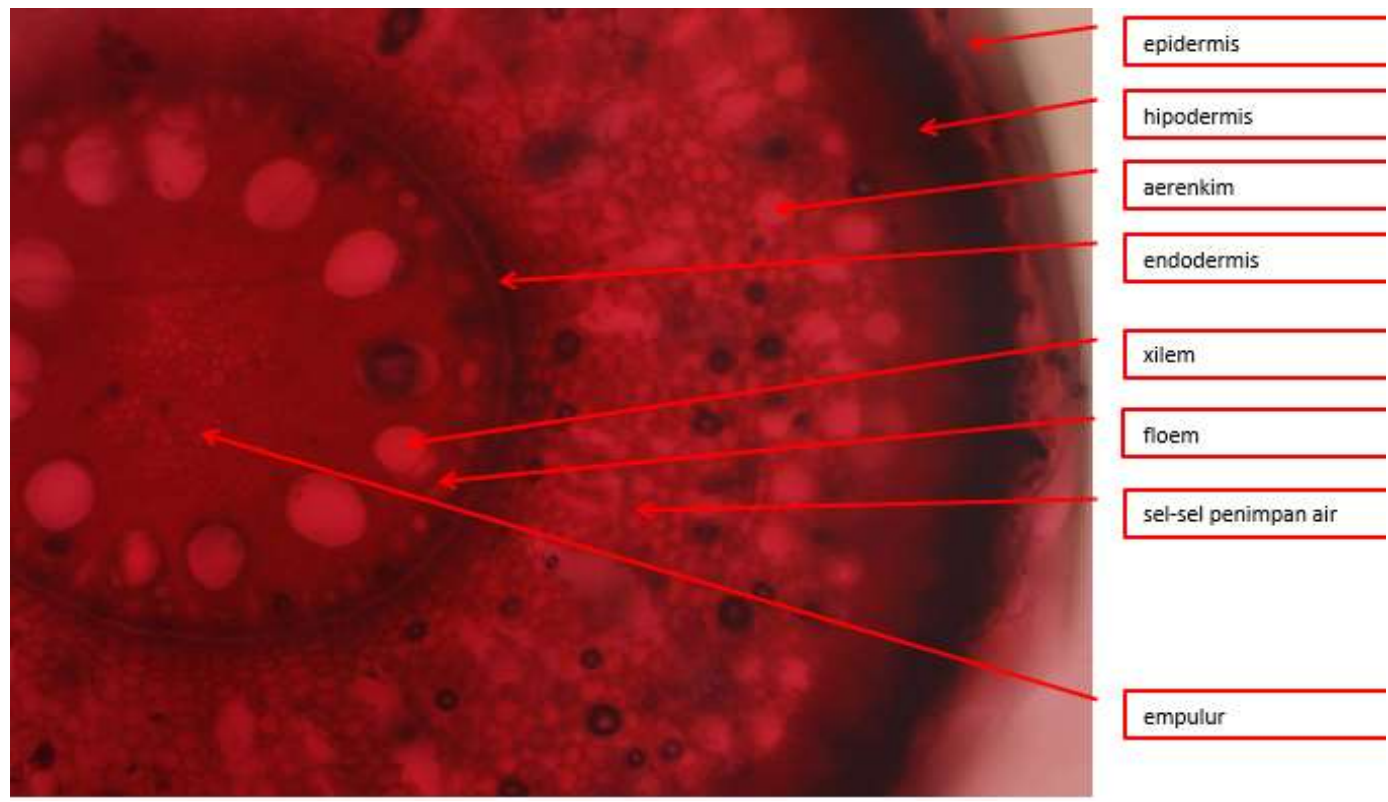

Gambar 2. Anatomi akar $2 \mathrm{~mm}$, pada lahan recovery $(\mathrm{M}=100 \mathrm{x})$ 


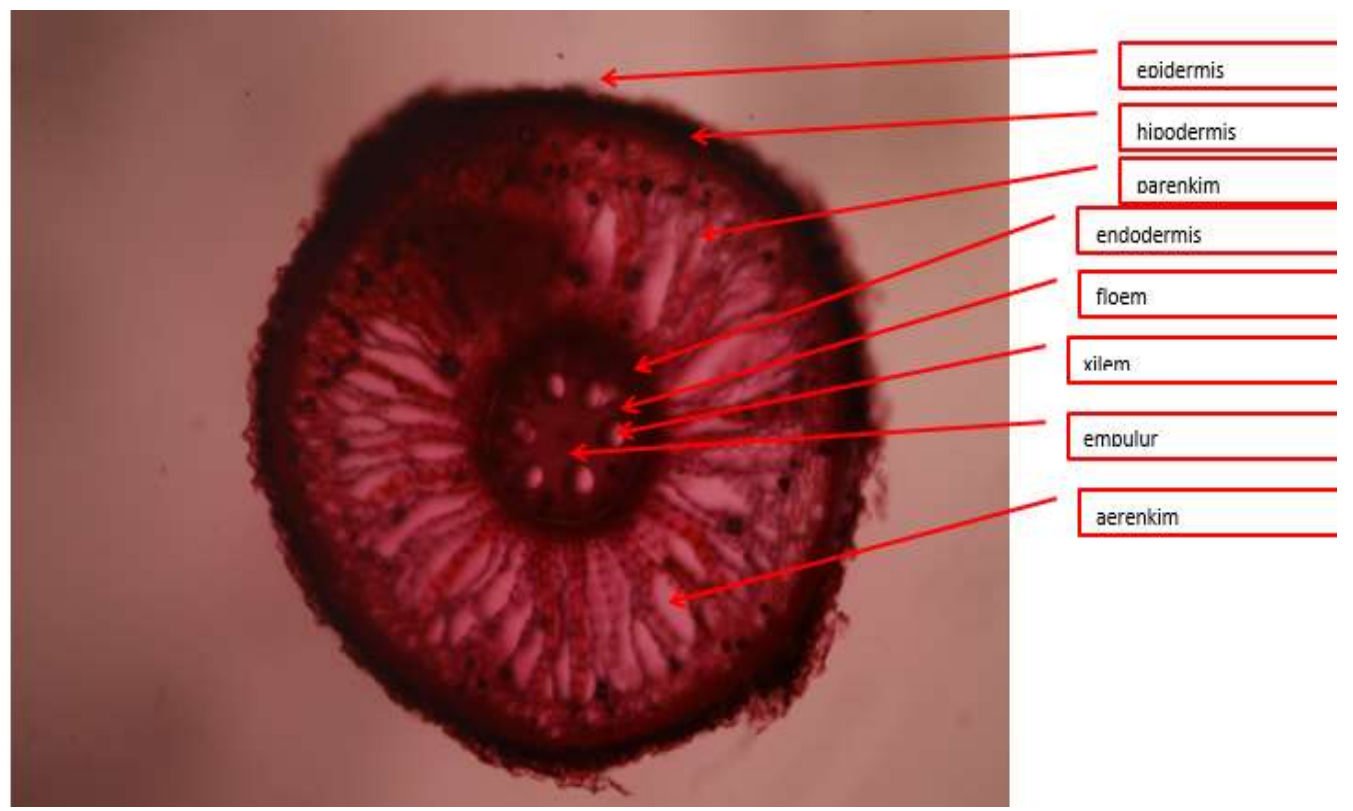

Gambar 3. Anatomi akar $2 \mathrm{~mm}$, pada lahan unrecovery $(\mathrm{M}=40 \mathrm{x})$

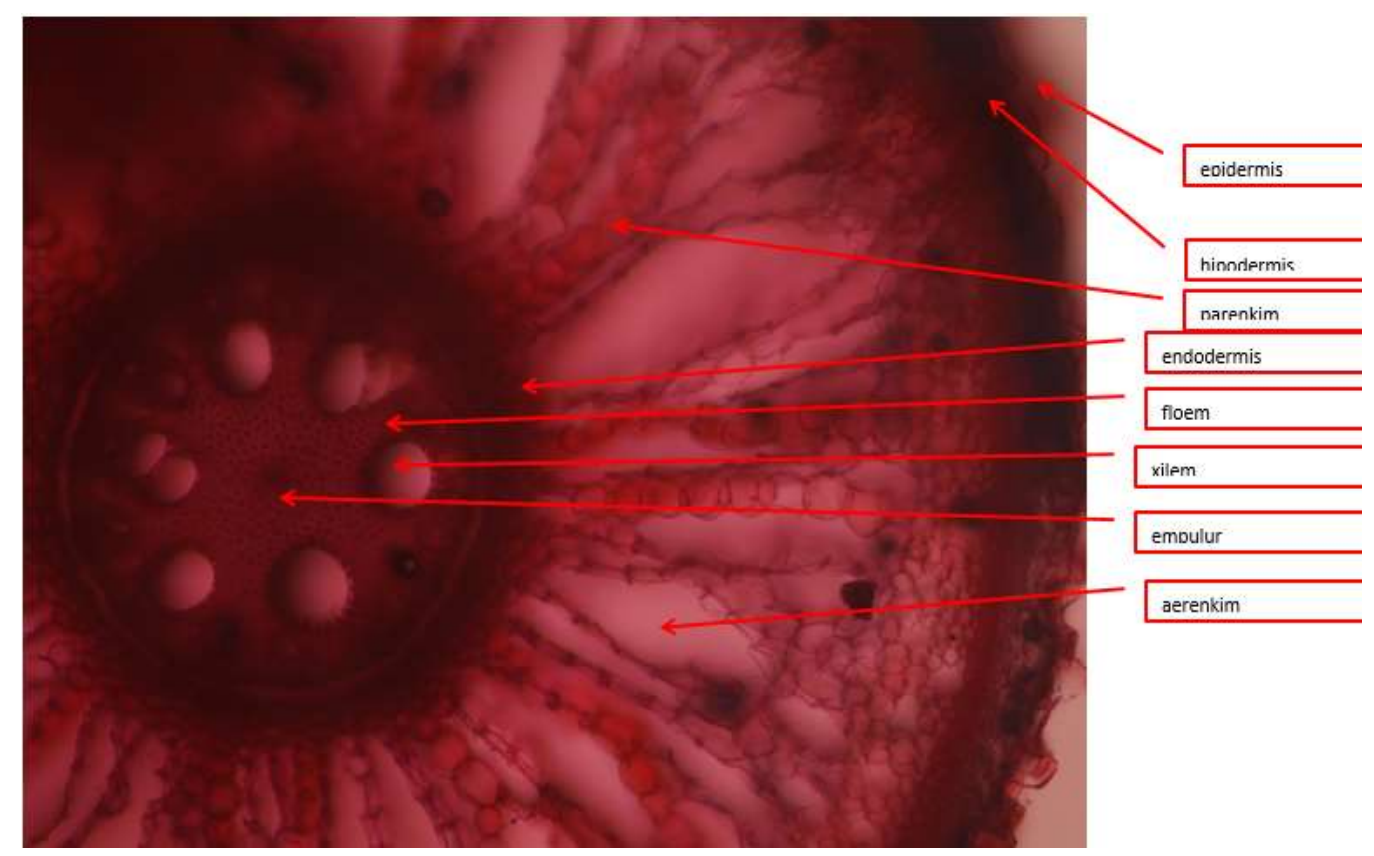

Gambar 4. Anatomi akar $2 \mathrm{~mm}$, pada lahan unrecovery $(\mathrm{M}=100 \mathrm{x})$

\section{KESIMPULAN}

Morfologi bunga dan ukuran stomata salak pondoh di Salamsari, Ngablak, dan Banyuadem Kabupaten Magelang tidak terdapat perbedaan nyata. Sedangkan, anatomi akar berbeda pada susunan sel korteks pada lahan recovery lebih rapat dan beraturan dan pada lahan unrecovery, susunan sel korteks akar lebih tidak beraturan dan banyak rongga udara.

\section{UCAPAN TERIMA KASIH}

Terimakasih kepada Universitas Diponegoro untuk pendanaan Riset Pengembangan dan Penerapan (RPP) sumber dana selain APBN 
Universitas Diponegoro tahun anggaran 2020 nomor : 233-109/UN7.6.1/PP/2020.

\section{DAFTAR PUSTAKA}

Badan Pusat Statistik. 2019. Produksi Tanaman Buah-buahan 2019. Jakarta, BPS Indonesia. https://www.bps.go.id/indicator/55/62/1/pro duksi-tanaman-buah-buahan.html

Cambell, N.A, J.B. Reece and L.G.Mitchell. 2003. Biologi. (Terjemahan: L.Rahayu, E.I.M Adil, N Anita, Andri, W.F Wibowo, W.Manalu). Erlangga, Jakarta.

Fatimah, S. 2013. Analsis Morfologi dan Hubungan Kekerabatan Sebelas Jenis Tanaman Salak. Universitas Trunoyono Madura. Agrovigor 6(1): 1-15.

Fenta, B.A., S.E, Beebe, K.J. Kunert, J.D. Burridge, K.M. Barlow, J.P. Lynch, C.H. Foyer. 2014. Field phenotyping of soybean roots for drought stress tolerance. Agronomy. 4:418435.

Girsang, E., I. N. E. Lister, C. N. Ginting, A. Khu, B. Samin, W. Widowati, S. Wibowo, \& R. Rizal. 2019. Chemical Constituents of Snake Fruit (Salacca zalacca (Gaert.) Voss) Peel and in silico Anti-aging Analysis. Mol Cell Biomed Sci. 3(2): 122-8.

Hakim, M. S., P. Dewanti, S. Hartatik, Slameto \& T. Handoyo. 2020. Efek pemberian potassium terhadap recovery tanaman padi (Oryza sativa L.) setelah cekaman kekeringan. Jurnal Ilmu Dasar 21(2): 115122.

Hastuti, S. 2013. Strategi Pengembangan Salak Pondoh Pronojiwo Kabupaten Lumajang. Jurnal Ilmiah INOVASI 13(3): 233-240.

Herawati, W., T. Chasanah, dan Kamsinah. 2012. Karakteristik Salak Lokal Banyumas (Salacca zalacca (Gaert) Voss sebagai Upaya Pelestarian Spesies Indigenous. Prosiding Seminar Nasional: Pengembangan Sumber Daya Pedesaan dan Kearifan Lokal Berkelanjutan II, 239-244.

Herawati, W, A. Amurwanto, Z. Nafi'ah, A. M. Ningrum, \& S. Samiyarsih. 2018. Variation analysis of three Banyumas local salak cultivars (Salacca zalacca) based on leaf anatomy and genetic diversity. BIODIVERSITAS 19(1): 119-125.

Joshua dan K. Sinuraya. 2018. Review jurnal: Keanekaragaman aktivitas farmakologi tanaman salak (Salacca zalacca). Suplemen 16(1): 99-106.

Lynch, J.P., K.M. Brown. 2012. New roots for agriculture: exploiting the root phenome. Phil. Trans. R. Soc. B. 367:1598-1604.

Pulakiang, A. R., J. S. Polii-Mandang, dan S. Sompotan. 2017. Beberapa karakter morfologis tanaman salak (Salacca zalacca (Gaert) Voss) di kampong Bawoleu, Kecamatan Tagulandang Utara, Kabupaten Kepulauan Siau Tagulandang Biaro. Eugenia 23(2): 48-57.

Saleh MS, Siddiqui MJ, Mediani A, Ismail NH, Ahmed QU, So'ad SZ, Saidi-Besbes S. 2018. Salacca zalacca: A short review of the palm botany, pharmacological uses and phytochemistry. Asian Pac J Trop Med 11(6): 45-52.

Suharti, Mukarlina, dan D. Gusmalawati. 2017. Struktur Anatomi Akar, Batang dan Daun Gaharu (Aquilaria malaccensis Lamk.) yang Mengalami Cekaman Kekeringan. Protobiont 6(2): 38-44.

Taluta, H. E., H.L. Rampe, dan M. J. Rumondor. 2017. Pengukuran Panjang dan Lebar Pori Stomata Daun Beberapa Varietas Tanaman Kacang Tanah (Arachis hypogaea L.). Jurnal MIPA UNSRAT Online 6(2): 1-5.

Widyantika, H. 2018. Pengaruh Variasi Buah Salak pada Pembuatan Selai Pancake terhadap Sifat Fisik, Sifat Organoleptik, dan Kadar Serat. Yogyakarta: Poltekkes Kemenkes

Zaed, A. S. 2015. Pengaruh Perbedaan Sumber Polen dan Varietas Salak (Salacca zalacca Gaertener Voss.) terhadap Kualitas Buah. Agrovigor 8(1): 51-57.

Zelitch, I. (2018). Stomata and Water Relations in Plants. New Haven: The Constitut Agricultural Experiment Station 